\title{
Built Form Properties as Sign and Symbols of Patron Political Ideology
}

\author{
(Ciri Bentuk Binaan sebagai Tanda dan Simbol Penaung Ideologi Politik) \\ Alice Sabrina Ismail* \& Erna Nuralia Zhaharin \\ Department of Architecture, Universiti Teknologi Malaysia, Malaysia
}

\begin{abstract}
This paper discusses on the study of architecture as a sign system by analyzing its generic elements-form making based on the Western philosophers. In addition, this study investigates how built form act as a sign and contribute to major symbolic content which gives concrete expression to the socio cultural and political phenomenon. In this case, prominent buildings found in the modern context are used as examples to explain how they are capable of communicating the intentions of patrons to users as well as transmitting messages when users invest the building with meaning. This is important as built form do not only symbolize norms of society and social structure as well that relative to world view, hierarchies and the like. This paper is significant as it develops a systematic approach to understand the relationship between sign symbols and material culture. This understanding makes substantive contribution to elucidate the production of meaning in relation to the built environment across different cultural settings. Furthermore, it provides an insight that the meaning of the built environment is dependent on human intentions and purposes as conceived in a particular cultural context like Malaysia and the global scene. Therefore, it provides a clear framework to lead architectural scholars, designers and researchers, who are interested in analysing the themed environments, towards a better understanding of the structural relationship that exists between the built environment and social culture in contemporary society.
\end{abstract}

Keywords: Politics and Architecture; Material Culture; Built Form; Architecture Sign and Symbol

\section{INTRODUCTION}

In common terms, architecture is understood as the art or practice of designing and erecting buildings, or in other words it is the combination of building and art (Ismail \& Rasdi 2010). Architecture by itself is acknowledged as a self-referential object due to the basic generic elements such as volume, line, plane, surface, mass, material, and structure that constitute it. These fundamental elements become important in themselves, which is when combined, interacting and united they make up the physical and visual form that helps to define the existing context and space (Borch et al. 2014). Architecture occupies and shapes the physical social context as well as influencing the perceptual nature of human behavior. This is possible as the aesthetic manifestation of architecture satisfies and motivates the human emotion. Physical appearance and visual impression of architecture not only help engage the user to its content, similar to the reaction of a picture-object that engages our disposition to the world, but also allows the user to use physical senses to recognize the architectural function (Venturi \& Brown 2004). Due to this interactive situation, communication between users and the built environment therefore exists, as architectural function helps organize the space of human actions.

\section{ARCHITECTURE AS A 'SIGN' AND FORM OF COMMUNICATION}

The assumption that architecture is invested with meaning and is a means of conveying meaning is not a new one.
Throughout history, architects and writers in the architectural field have argued and discussed this subject. Many contend that architecture is more than utilitarian since architecture is the evidence of social life (Dovey 2014). Architecture is capable of conveying social and intellectual meaning including expressing the religious belief and political practice of society through its physical and visual form (Rowland $\&$ Howe 2001). Architecture may also be understood from another aspect, which involves the structured relationship that exists between the buildings with its immediate surrounding environment: both at the time it was built and thereafter (Rapoport 1988).

Since architecture by itself is a self-contained sign system, with its own grammar and syntax, most scholars in the field of architecture attempted to import structuralist methodology to understand architecture, as they believe that architecture can be read as 'text' (Whyte 2006). This structuralist approach to understanding architecture was based upon the assumption that architecture was a 'sign system' - a means of communication that was analogous to verbal or written language. Examples of this approach are seen in the work by past scholars where they state that architecture can be understood by analogy to language; as a 'code' capable of being used to communicate the intentions of the patron to the building user. The physical manifestations of architectural form can be read through a recognized code, to be interpreted by the user (King 2004). This is because the dynamic qualities of form help translate the building function into a non-verbal coding system which makes communication with the user possible (Habraken 2000). 
Architectural form attributes not only produce messages potentially for individual users. Architecture is also capable of acting as a sign for large groups of people or audiences: a form of mass communication. As stated by Jencks, architecture seems to offer messages that have mass appeal, that lend themselves to being taken for granted even when they are not highly conventional, but there are at the same time inventive and heuristic aspects to these messages (Aureli 2008). Architectural objects besides permitting and promoting certain functions, they permit and promote critical readings, in which one compares them with prior (and subsequent) means of societies' ideologies and inhabitation (Ismail 2008). From this, it is appropriate to say that architecture is a cultural object, and is closely tied to a particular social context and historical moment (Goodman 1998). Owing to its utilitarian value and its constituent elements, which are capable of symbolically communicating the function it permits and promotes based on codes, architecture therefore can exert various meanings at different moments for different groups in society (Nitzan-Shiftan 2005). Architecture may not carry the same meaning for everyone and for all the time. Meanings may change, in the extreme becoming the opposite or simply different (Sonne 2004; Peters 2004). However, architecture does have the potential to transmit messages to the mass populace. For that matter, it is commonly used as a tool in the service of politics by a ruling government, to serve as a symbol of the state. Architecture has been manipulated by ruling bodies throughout history and across the globe as symbols of the state to support specific regimes. Architecture is used to mediate forms of political power in order to propagate political ideologies to the pluralist society (Vale 1992). These ruling bodies symbolically make use of the built environment as a tool to exercise their authority, due to the physical existence of the built form allowing them to declare and enact their political intention.

Scholars mentioned that this phenomenon often occurred in many modern states throughout the world due to the uprising of political regimes, since they greatly relied on symbols in the form of architecture, rituals, ceremonies and displays to project the idea of legitimation (Sudjic 2005). These potential symbols therefore can be drawn upon by the ruling parties to assist them in gaining populist support. By arousing nationalistic emotions of the masses and maneuvering the populace sentiments, they aim to maintain their status and position in society. The ruling regime's main political ambition in modern states, and particularly in newly independent countries, is to utilize architecture for the purpose of unifying the masses; and representing achievement and gaining acknowledgement (Coaldrake 2002; Borch et al. 2014).

\section{ARCHITECTURE FOR THE RULING BODY}

The need to integrate the masses has always been a major issue for all countries in the world, and especially for newly independent states which have previously undergone the process of decolonisation. These newly independent states were divided by the colonialist into opposing groups. As a result, in remote rural places often a person's loyalty still remains local rather than national or regional integration. To overcome this situation, most post-colonial governments try to integrate or unify the population to follow one ruling body by making various programs such as the usage of icons in the form of buildings to promote the idea of nationalism. Many buildings in these newly independent nations seem to portray images referencing ethnic, cultural or religious belief in order to potentially evoke the nationalistic sentiments among the masses (Vale 1992; Bohme 2014). Nationalism is the main vehicle for a ruling body to secure their political legitimacy and power in this newly independent society. Works of architecture become the major focus for political leaders to render their national ideologies. Architecture is the best tool as it metaphorically communicates to the masses through form and other elements (Vale 1992; Bohme 2014). A building can overwhelm due to the magnitude of its physical presence. It can also lend visual prestige to its sponsors and help to reinforce their political power, as the work of architecture has a dominant influence in the control of the conduct and action of others (Coaldrake 2002; Borch 2014).The main interest of the ruling government in newly independent states is to treat architecture as a visible sign of progress to gain global recognition from other nations: that is, a political need for the new ruling regime to - be more noticeable and to be more supreme (Sudjic 2005). Scholars proposes that there are two main reasons for this political act. Firstly, to show what they have achieved is equal to other developed nations namely the West, and secondly, to gain and claim social acknowledgement from the local masses. In order to achieve this recognition, the ruling governments erect monumental buildings with a modern appearance parallel to a global audience's preferences. The kind of building design that may symbolise the political power of a ruling regime will be addressed in depth in the next section by analysing series of prominent building examples in the Malaysian scene. Main generic architectural aspects which is 'built form' - will be discussed in detail through a series of prominent building examples in local contexts to demonstrate the relationship with political agenda. This study is significant as it elucidates wide range of prominent buildings representing different typologies involving religious built form, government and commercial buildings, official residence as well as educational institution found in both local context to represent building as symbol of patrons ideology. In addition, this study also substantial as it offers a solid, scholarly account of farreaching analysis on the study of built form by introducing new ways of looking at buildings architectural attributes as a system of 'sign.' This study builds upon the theories and concepts outlined by Saussure on sign relations, Barthes on levels of signification and Gottdiener on reading the material culture as reliable ways for analysing and understanding the built form to develop a new methodological approach.

This study is significant because previous studies done by scholars in the field of politics and architecture, only focuses on discussion of built form and politics in specific setting and context from the aspect of documentation on 
building historical development (Jones 2001; Borch et al. 2004) and classification of building styles (Hirst 2005; Gale 2004). None of the past literature provides a study on the relations between architecture and politics, in an attempt to systematically showcase and document series of case studies involving various typologies of building like religious built form, government and commercial buildings, official residence as well as educational institution namely found in the Malaysian context. In other words, highlight the aspects of 'form' involving aesthetic, compositional, and organizational elements and elucidate the existence of built form interrelated with the nation's issues, influential individuals and leaders political agenda. Before analysing this series of building, the next section will firstly elaborate on the method used to conduct the analysis.

\section{SEMIOTICS AS METHOD FOR BUILDING ANALYSIS}

This research will be using case study method where direct observation on the chosen case study will be conducted in parallel with literature review to represent each case study. Interpretivism paradigm is chosen as the research method as it involves researchers and the residents to interpret elements. It is therefore encouraging human involvement into study of interpretation. To analyse data from observation, method such as semiotic is used as it involves the study of meaning and sign. This method of analysis is considered as an important contribution as it introduces new ways of looking at building as a system of 'sign' as well as proposing indicators to investigate this matter in depth. Data from observation then is built upon the theories and concepts outlined by Saussure on sign relations, Barthes on levels of signification and Gottdiener on reading the built environment as reliable ways for analysing and understanding the design of prominent buildings. Semiotics, or semiology, is the study of signs and symbols and how meaning is constructed and understood (Fiske 1990). Semiotics covers three main areas of study. These are the study of sign itself, the codes and systems into which signs are organised and the culture within which these codes or signs operate (Leeuwen 2005). A sign is defined as a display of structure, an act, gesture or something physical perceivable by human senses that conveys an idea, desire, information or command. However, things only become a sign when meaning is invested in them (Leeuwen 2005). Since the study of a sign may not be divorced from the concrete form of social intercourse, and cannot exist, as such, without it, the theory of semiotics therefore is commonly applied to the fields of art, literature, anthropology, and architecture (Chandler 2017). Semiotics is also widely applied in architecture to investigate how people project meanings onto the built form (Chandler 2017). There are two dominant models in the study of semiotics. The founders of these two schools were C.S Pierce and linguist, Ferdinand Saussure. As Saussure's work will benefit this present study, his ideas on 'sign' relations, how a 'sign' operates and the way it conveys meaning will be discussed in detail.
THE BUILDING AS A 'SIGN' - FERDINAND SAUSSURE

Ferdinand Saussure founded the structuralism school of thought, proposing a dualistic notion of signs. According to Saussure (1966), a sign "doesn't exist in reality and it is formed by the associative link between the signifier and the signified." In his linguist theory, the signifier is the sound and the signified is the thought. As put forth by Saussure (1966), "a sign is not a link between a thing and a name, but between a concept (signified) and a sound pattern (signifier)" - to form a meaning-imbued 'sign.' Saussure (1966) also states that "signs too can exist only in opposition to other signs. That is, signs are created by their value relationships with other signs. The contrasts that form between signs of the same nature in a network of relationships is how signs derive their meaning." Since the meaning of a sign is also determined by how a sign is differentiated from other signs, therefore it involves the mental concept (signified) to categorise meaning to help understand the sign better. For Saussure, this mental concept (signified) is constructed by people and is influenced by the culture or subculture to which they belong (Fiske 1990). Saussure's model of signs is of value for this study, as there is a need to understand how built forms operate as a meaningful sign.

To clarify this, the example of the sign MOSQUE to represent built form is used as shown in Figure 1. As a sign, it is composed of the signifier - the word or sound pattern 'mosque,' and the signified - mental concept of 'mosque,' which one has of this particular type of building. The relationship between the mental concept of (mosque)signified and the word or sound pattern (signifier) - 'mosque' is known as signification. Referring to the Saussure model, the mental concept (signified) is also a product of a particular culture. Therefore the mental concept (mosque) may be articulated differently by each individual or reader, who is influenced by the culture they come from and belong to.

Since the mental concept which we articulate will be different for every one of us, Saussure also stresses the arbitrariness of the sign (Saussure 1966). On this matter, he states that the relationship between the signifier and signified is determined by conventions, rule and agreements among users (Holdcraft 1991; Fiske 1990). There are formal conventions that fix the meaning and enable one to experience similar signs and communicate with each other. For example there is a formal convention which is agreeable to all within our culture that the sign MOSQUE refers to a building and not a platter of food. Because the relation that exists between the signifier and the signified is arbitrary, codes are also developed and used to help us learn what some signs mean (MacGregor 1985). In addition, codes which are defined as, "sets of signs and rules for their use by semioticians also help to simplify phenomena in order to make it easier to communicate experiences" (Hurwitz 1993). Meanings, therefore, are activated within the repertoire which the code offers us (Fiske 1990). Although Saussure's work is best suited for the present research, as his model of signs forms the basis of understanding how signs work, nevertheless there are limitations to his study. He did not describe in detail the 


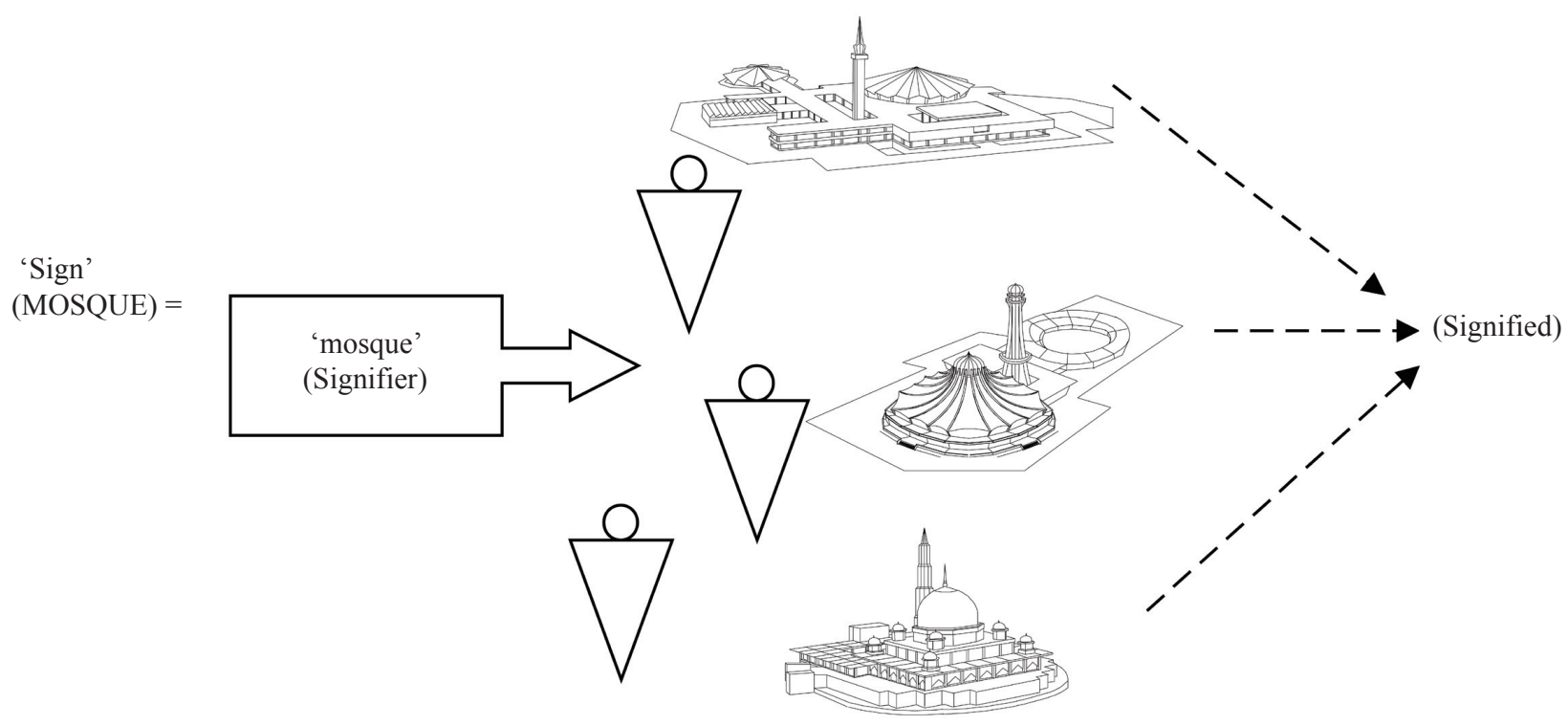

FIGURE 1. Signifier - Signified relationship

social cultural experience, expression and conventions when dealing with the understanding of signs. This is because Saussure's model of the sign only focused on denotation rather than at the expense of connotation (Fiske 1990). As also argued by Smith (2001), “one limitation of Saussure's approach was his understanding of a sign that an object $\mathrm{x}$ comes to have a meaning $\mathrm{y}$ within a certain structure. The process of meaning making thus, resembles 'pattern matching.' Due to this limitation, Roland Barthes' work is referred to next, as he elaborates on Saussure's model of signs in a more extensive way. Barthes stated that the bond between the signifier and signified (mental concept) is also dependent on social and cultural conventions. Furthermore, Barthes analysed the meaning of signs based on orders of signification. These are denotation, connotation and myth. His application in the material culture is known as socio semiotics (Hawkes 2003).
THE BUILDING AS AN 'INTERACTIVE SIGN' - ROLAND BARTHES

Socio-semiotics articulates the material context of daily life and the signifying practice within a social context, where all meanings arise from a more articulated codified dimension. Here, the systems of signification (relationship between the signifier and signified) are multileveled structures which not only contain denotative signs but also connotative signs when particular cultural codes are ascribed to these signs (Barthes 1988). The first order of signification is that of denotation: at this level there is a sign consisting of a signifier and a signified. Connotation is a second-order of signification which uses the denotative sign (signifier and signified) as its signifier and attaches to it an additional signified. In this framework, a connotation is a sign which derives from the signifier of a denotative sign (so denotation leads to a chain of connotations) (Barthes 1988) as shown in Figure 2.

\begin{tabular}{|c|c|c|c|}
\hline \multicolumn{3}{|c|}{ SIGN } \\
\hline $\begin{array}{c}\text { Denotation } \\
\left(1^{\text {st }} \text { level of signification }\right)\end{array}$ & Signifier & $\begin{array}{c}\text { Signified } \\
\text { (mental concept })\end{array}$ & \\
\hline $\begin{array}{c}\text { Connotation } \\
\left(2^{\text {ndt }} \text { level of signification }\right)\end{array}$ & Signifier & $\begin{array}{c}\text { Signified } \\
\text { (mental concept })\end{array}$ \\
\hline
\end{tabular}

FIGURE 2. Denotation and connotation ( $1^{\text {st }}$ and $2^{\text {nd }}$ level of signification)

In other words, denotation, or first order of meaning can be described as the relationship between signifier and signified within the sign. This refers to the definitional, literal meaning of a sign. This relationship can extend further as a sign may also have additional values. Here, the sign can also become a signifier of another sign (connotation) or second order of meaning, which signifies cultural values such as status structure in society. The level of connotation may also develop further when it combines with denotation to produce ideology. The sign becomes its own referent as a third order of meaning (myth), where it becomes a hypostatization that condenses an entire ideology in a single word or image 
(Barthes 1967). In other words, the function of myths is to help us to make sense of our experiences within a culture. Myth also expresses and serves to organise shared ways of conceptualising something within a culture (Barthes 1988). An example is a daily use object such as a 'pen.' At the denotative level, this object is generally associated with its daily function as a writing tool. The 'pen' however may also be susceptible to other meaning when it is linked or being connoted by ideology of high status. At a connotative level the pen may parade a certain sense of wealth, status or position. This meaning could also include other associations through condensation and hypostatization at the mythic level such as progress, technology or intellectuality (Barthes 1988).

The first (denotative) order (or level) of signification, therefore is seen as primarily representational and relatively self-contained. The second (connotative) order of signification reflects 'expressive' values which are attached to a sign. In the third (mythological or ideological) order of signification, the sign reflects major culturally-variable concepts underpinning a particular worldview, such as masculinity, femininity, freedom, individualism, objectivism, Englishness and so on (Chandler 2017). To understand how Barthes' theory of orders of signification relates to the present study, the Figure 3 can be referred as an example. At the denotative level, the above is a diagram of an image of a building, and by bringing together all its physical architectural elements such as dome, minaret, arches, entrance portal, into relations, we then identify it as a mosque. At a connotative level, we then associate mosque with the existing culture and society. The mosque therefore is viewed as a place of Muslim worship, a religious learning center for the Muslim, a Muslim communal place and a spiritual place. At a mythic level, we understand the mosque as a sign, activating the myth of Islamic religion, status, identity, power and glory. In this case, the mosque may be a statement of Islamic ruling, ideological symbol for the propagation of Islamist thinking, symbolic representation of Islamic power and presence, dominion of Islamic government and so forth. Barthes' work, therefore, is of greater value for the current research, as the aim of this study is to read and interpret the meaningful nature and concepts that are embodied in the state mosque as a sign which is bound to a particular social context and cultural setting. In this regards, Barthes' interactive idea of meaning is relevant for this work because he clearly defined that signs work in order of signification, and, during the process of signification, interaction occurs between the sign with the user's experience and his or her social cultural position. As a result, diversity of interpretations is obtained, instead of one defined or literal meaning. In order to understand further how socio-semiotics is applied in analysing the built environment, the work by Mark Gottdiener will be referred to next, as the main reference for this study. This is because he explicitly focuses on the subject of sociosemiotics and its application to analyse the phenomena of material culture. Gottdiener uses the organisation of signs for his research to understand how ideology articulates with material forms or, in other words, how material forms are encoded through ideological meanings which are engineered into form. By understanding this, one will be able to decode and 'read' the meaning of the material culture. Although his research focuses on Las Vegas as an environmental setting, his study provides methodological insights for the study of other settings such as buildings which are also products of social and political contexts.

$$
\begin{gathered}
\text { Connotation } \\
2^{\text {nd }} \text { order of signification }
\end{gathered}
$$

Myth
$3^{\text {rd }}$ order of signification

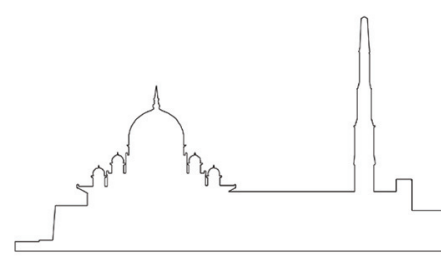

Bringing together physical elements into relations - define it as a specific building type (mosque)
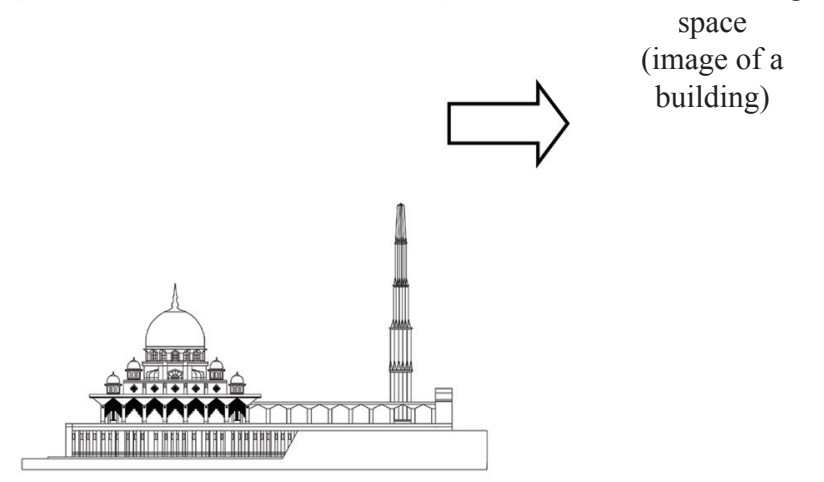

\author{
Denotation \\ $1^{\text {st }}$ order of signification
}
Line enclosing Association with existing culture and society (expressive values attached to the mosque) - may define it as a place of Muslim worship

\author{
Hypostatization \\ that condenses an entire \\ ideology \\ (content of the mosque \\ codified by cultural \\ dimension and religious \\ ideologies from \\ particular worldview) \\ - may define it as \\ symbolic representation \\ of Islamic power and \\ presence
}

FIGURE 3. Example of denotation, connotation, myth $\left(1^{\text {st }}, 2^{\text {nd }}\right.$ and $3^{\text {rd }}$ level of signification $)$ using religious built form as sample for analysis 
WORK OF GOTTDIENER - THE RELATION BETWEEN SOCIO-SEMIOTICS AND THE MATERIAL CULTURE

Gottdiener (1995) introduces the socio-semiotic model of the sign to describe the way ideology articulates with material forms. According to him, socio-semiotics accounts for a two way process to present symbolic interaction in daily life: first, is the articulation of ideology and second, is the material forms. The term 'ideology' here is defined as the value system of a social group. A value system is correlated to the content of a sign, whereas materiality is correlated to the expression of sign (Gottdiener 1995) as depicted in Figure 4.

$\frac{\frac{\text { Non-codified ideology }}{\text { Codified ideology }}}{\text { Morphological elements }}$

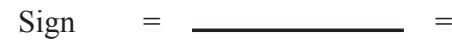

FIGURE 4. Decomposition of sign (socio-semiotic model of sign) Gottdiener (1995)

The 'content' then can be divided further to 'substance' and 'form.' The contents of form and substance are determined by the ideological culture of the society. This ideology, which belongs to a particular cultural practice, may be codified or non-codified ideology (Gottdiener 1995). The 'expression' is also divided further by substance and form. Both of these, however, refer to the object. In the case of the object, it may refer to the specific morphological elements or material existence of the object (Gottdiener 1995). In order to understand the way ideology relates to the built environment, Gottdiener also produces another type of socio-semiotic model using the same format as the above (Gottdiener 1995) as shown in Figure 5.

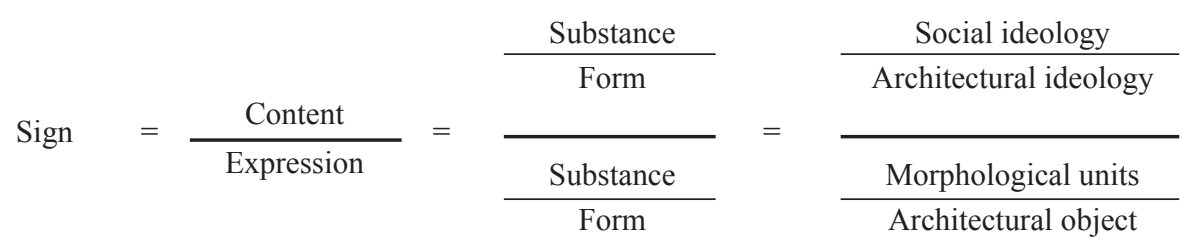

FIGURE 5. Decomposition of architectural sign (socio-semiotic model for architectural sign) Gottdiener (1995)

To explain how this socio-semiotic model in Figure 5 works for the built environment, Gottdiener carried out an analysis of the mall as his case study as shown in Figure 6. In the study of the mall, Gottdiener (1995) outlined that the mall as a built form is best understood as the intersecting site of two distinct structural principles. These two principles are the mall 'content' and its 'expression.' Since every sign is also a part of system of signification, which is structured by the paradigmatic and syntagmatic axes, these two separate orders of meaning are also important in reading the sign system which can be found at the mall. Gottdiener (1995) also states that the paradigmatic axes of the mall can also be referred to as the 'content' of the mall which involves the mall design motif, while the syntagmatic axis is referred to as the 'expression' of the mall. This second axis consists of the way the separate elements within the mall produce meaning through metonymy and contiguity as in Figure 6.

$$
\text { Mall (sign) }=\frac{\text { Content }}{\text { Expression }}=\frac{\text { Paradigmatic (design motif of the mall) }}{\text { Syntagmatic (elements within the mall) }}
$$

FIGURE 6. Reading of sign systems for the mall as a built form (Gottdiener 1995: 84)

Since the mall 'content' also involves the design motif of the mall which is to sell consumer goods, the codified ideology of the building hence articulates an ideology which is driven by the culture of the society that relates to consumption and consumerism (Gottdiener 2003). The mall 'expression', on the other hand, refers to the morphological elements of the mall that can stimulate consumer fantasies and at the same time attract shoppers, to promote purchasing. In this case, the 'expression' or syntagmatic axes of the mall involve the articulation of design elements within the built form such as the built form interior façade, its spatial layout and decorative features (Gottdiener 2003). For the purpose of this research, the decomposition of architectural signs proposed by Gottdiener seems suitable in describing the case 
study to elucidate the building as an object of social culture. This is because by looking at the content and expression of the building it is possible to describe the way cultural and political codes are articulated within the built form. This also includes an explanation of how the codified ideology of the chosen building articulates a particular ideology belonging to a society and culture.

INDICATORS TO READ THE CASE STUDY - THE BUILDING AS A 'SIGN'

Since the present study involves the reading of the building as a sign, there is a need to identify the architectural elements within the building. This is because Gottdiener's work focuses on describing the mall as a social product. Therefore, only two elements within the mall were identified by him. These are the spatial layout, and the facades and decorative elements of the mall. However, since the present research is about the building built form as a symbol of political ideology and belief system, the selection of elements within the building should be more specific and appropriate. For that reason, the work by scholars such as Leucking (2002), Weber (1995) and Ching (1996) on built form is referenced as they generated the appropriate elements for reading building design as a symbol of political power. They identified that that 'form' can be categorised as either as two or three dimensional. Two dimensional forms have width and height, which may also create the illusion of three dimensional objects, whereas three dimensional forms have depth as well as width and height. These are size, structural form and material expression involving scale and façade design (see Table 1). Therefore by combining principles from both Gottdiener's research and Leucking, Weber and Ching study, a suitable framework for the current study was generated. These new indicators to read the building as a sign are set out in the model in Figure 7.

$$
\text { Buiding (sign) }=\frac{\text { Content }}{\text { Expression }}=\frac{\text { Paradigmatic (design motif of the building) }}{\begin{array}{c}
\text { Syntagmatic (elements within the built form): scale, facades } \\
\text { and structural arrangement }
\end{array}}
$$

FIGURE 7. Reading of sign systems for the building as a case study

Based on the Figure 7, the reading of the building sign system is possible by recognising that signification that occurs with reference to two separate orders of meaning, the paradigmatic and syntagmatic axes. During the process of investigating the case study of building selection, the design motif and elements within the chosen building will be read, to unpack their symbolic meaning.

\section{CASE STUDY ON BUILDING FORM ANALYSIS IN LOCAL AND GLOBAL CONTEXT: THE RELATIONSHIP OF POLITICS AND ARCHITECTURE}

Architectural form attributes, such as visual and relational properties, are key components which may express political authority of the ruling body (Sonne 2004). Both of these attributes will be discussed below in turn by understanding various sample of case study found in the local context. The justification selection of case studies is chosen based upon three main criteria. These criteria are-i) referring to the ownership status of the building constructed by dominant or influential patron in society ii) the building purpose and function as countries prominent landmark iii) building that has significant value in terms of its contribution towards country's development iv) the selection of building typology represents the category type of religious built form, government and commercial buildings, official residence as well as educational institution. This is important to determine whether the built form design from various category symbolizes patrons' political ideology as well as influenced the country's societal, political and economic formation as outlined by the two main indicators sourced from the literature review. These indicators are building content and building expression involving - form (physical dimension scale and façade). Table 1 shows architectural design of built form as symbol of political ideology.

\section{CONCLUSION}

From the findings above, it is apparent that architecture is a form of 'sign' which may convey messages, when sign-users invest them with meaning with reference to a recognized code. From this, it can be said that architecture may symbolize the political ideology of a particular group or ruling body, as the symbols of authority are institutionally embedded in built form design elements - 'form.' Having discussed form as the key generic aspects that have been shown to represent political agendas of Malaysian nation it clearly indicates that built form embodies denotative and connotative message which are capable to portray concept of authority or domain to the society. By creating a sense of awe through spectacular, heroic projects and dominant built form is a political strategy for those in power to attract followers, besides advancing their superiority and leadership in society. From this understanding, therefore, provides a clear understanding as to what motivates the individual leaders to build and the nature of the elusive relationship between power and architecture. This is because buildings are symbols of human culture that can suggest many social and political interpretations of the conditions of a society in its internal organisation and its ideas of the nation-self. Understanding the nature of these leaders' political ambitions offers a worthy lesson for future researchers, designers and politicians to have objective voice and thoughtful consideration on the importance of describing architecture in its proper context and the need to design living 
TABLE 1. Architectural design of built form as symbol of political ideology

\begin{tabular}{|c|c|c|c|c|c|}
\hline $\begin{array}{l}\text { Building } \\
\text { category }\end{array}$ & $\begin{array}{l}\text { Intention of portraying } \\
\text { political ideology by } \\
\text { building patron } \\
\text { (content) }\end{array}$ & $\begin{array}{l}\text { Influence of political } \\
\text { ideology on building } \\
\text { (expression) Form } \\
\text { (physical dimension) }\end{array}$ & $\begin{array}{l}\text { Architectural } \\
\text { characteristics }\end{array}$ & $\begin{array}{l}\text { Case study in } \\
\text { local scene }\end{array}$ & Findings \\
\hline $\begin{array}{l}\text { Religious } \\
\text { built form } \\
\text { (State } \\
\text { mosque) }\end{array}$ & $\begin{array}{l}\text { To evoke feelings of } \\
\text { impressiveness in order } \\
\text { to be remembered by } \\
\text { its audience through the } \\
\text { - rebuilding of Islamic } \\
\text { imperial power and } \\
\text { reviving past } \\
\text { civilization in building } \\
\text { style and design } \\
\text { approach }\end{array}$ & $\begin{array}{l}\text { a) Massive horizontal scale } \\
\text { Scale draws attention to the } \\
\text { building's significance by } \\
\text { emphasizing its length, } \\
\text { large, wide and } \\
\text { horizontally massive with } \\
\text { dramatic sculptural effect } \\
\text { incomparable to human } \\
\text { proportion symbolize the } \\
\text { ruling body's authority. }\end{array}$ & $\begin{array}{l}\text { - Monumental, massive } \\
\text { grandeur appearance } \\
\text { - Palatial setting } \\
\text { - Designed as an identifiable } \\
\text { structure which can be } \\
\text { viewed from miles away } \\
\text { - Stands as a distinct form in } \\
\text { an open space in which it } \\
\text { sits on a man-made platform } \\
\text { floating on the Putrajaya Lake. } \\
\text { - The built form dominates the } \\
\text { open site due to its outstanding } \\
\text { vertical elements such as the } \\
\text { minaret }\end{array}$ & $\begin{array}{l}\text { FIGURE 8. Position } \\
\text { and setting of Putra } \\
\text { Mosque (Ismail 2008) }\end{array}$ & $\begin{array}{l}\text { Architectural } \\
\text { attributes and } \\
\text { properties of Putra } \\
\text { Mosque during the } \\
\text { date it was } \\
\text { commenced to } \\
\text { symbolise the } \\
\text { political ideology of } \\
\text { Malaysian leader } \\
\text { and Islamic vision } \\
\text { to gain acceptance } \\
\text { from local and } \\
\text { global audience } \\
\text { (Muslim nations) }\end{array}$ \\
\hline $\begin{array}{l}\text { Official } \\
\text { residence } \\
\text { (royal/ } \\
\text { presidential } \\
\text { palace) }\end{array}$ & $\begin{array}{l}\text { To lend visual prestige } \\
\text { and symbolize dignity } \\
\text { of the patron by } \\
\text { - capturing the viewer's } \\
\text { attention, through } \\
\text { perceptual arousal }\end{array}$ & $\begin{array}{l}\text { b) Heterogenous Facade } \\
\text { Façades with heterogeneous } \\
\text { elements capable of } \\
\text { conveying meaning and may } \\
\text { symbolize the status of the } \\
\text { building patron in society. } \\
\text { Heterogeneous façade } \\
\text { consists of a combination } \\
\text { of vertical and horizontal } \\
\text { figures such as openings } \\
\text { and sculptural details in } \\
\text { various shapes and sizes } \\
\text { placed at multiple orientation } \\
\text { and distances. These figures } \\
\text { which are symmetrically } \\
\text { arranged according to formal } \\
\text { ordering principles will } \\
\text { produce a dominant } \\
\text { appearance due to its } \\
\text { articulated composition. }\end{array}$ & $\begin{array}{l}\text { - Projects an impressive play } \\
\text { of façade elements and } \\
\text { picturesque decoration } \\
\text {-Façade is richly decorated } \\
\text { with floral finials, } \\
\text { embellishments and sculptural } \\
\text { elements as well as series of } \\
\text { dome in various shapes with } \\
\text { pointed arches arranged in } \\
\text { hierarchical organisation at the } \\
\text { roof, body and base section. }\end{array}$ & $\begin{array}{l}\text { FIGURE 9. Sculptural } \\
\text { façade of National } \\
\text { Palace } \\
\text { (Ismail 2010) }\end{array}$ & $\begin{array}{l}\text { Architectural } \\
\text { attributes and } \\
\text { properties of } \\
\text { National Palace in } \\
\text { the style of the } \\
\text { Malay and Islamic } \\
\text { architecture } \\
\text { signifies the ruling } \\
\text { authority of the } \\
\text { Malaysian monarch } \\
\text { as the Islamic leader } \\
\text { and Chief of Justice. }\end{array}$ \\
\hline $\begin{array}{l}\text { Government } \\
\text { building } \\
\text { (adminis- } \\
\text { trative } \\
\text { centre) }\end{array}$ & $\begin{array}{l}\text { To reinforce the } \\
\text { patron's immediate } \\
\text { authority by } \\
\text { - representing the idea } \\
\text { of dominancy and } \\
\text { control through the use } \\
\text { of overpowering built } \\
\text { form outstands the } \\
\text { surrounding context. }\end{array}$ & $\begin{array}{l}\text { c) Location and position } \\
\text { Location of building form } \\
\text { is defined by its placement } \\
\text { on the existing site. } \\
\text { Position of the building } \\
\text { form can give a visual } \\
\text { impact to the audience. } \\
\text { For example, if the building } \\
\text { is located on a higher } \\
\text { ground level at the top of } \\
\text { the hill or in the middle of } \\
\text { an open lake, it will be } \\
\text { prominent and may convey } \\
\text { that the building's creator } \\
\text { intends it to be noticeable } \\
\text { and recognized. If the } \\
\text { positioning of the form is } \\
\text { stretched out, or stands out } \\
\text { as a distinctive and } \\
\text { prominent object in an open } \\
\text { space, it will result in a } \\
\text { broad face feature to the site. }\end{array}$ & $\begin{array}{l}\text { - Strategically place on top } \\
\text { of hill. } \\
\text { - Project massive building } \\
\text { structure covering a large } \\
\text { open site. } \\
\text { - Portray the building as } \\
\text { terminus point for a long } \\
\text { axial path at the opposite end. } \\
\text { - Building gives a sense of } \\
\text { grandeur placement from afar. } \\
\text { The direct approach along a } \\
\text { straight axial path towards } \\
\text { the building sets the } \\
\text { authoritative scene. }\end{array}$ & $\begin{array}{l}\text { FIGURE 10. The } \\
\text { Perdana Putra (Official } \\
\text { Malaysian Prime } \\
\text { Minister Office (Ismail } \\
\text { 2008) }\end{array}$ & $\begin{array}{l}\text { Architectural } \\
\text { attributes and } \\
\text { properties of the } \\
\text { Perdana Putra } \\
\text { official } \\
\text { administrative centre } \\
\text { of Malaysian } \\
\text { government in } \\
\text { contemporary } \\
\text { design idiom } \\
\text { tempered with } \\
\text { elements of } \\
\text { historicism not } \\
\text { only symbolises } \\
\text { patron's political } \\
\text { ambition of progress } \\
\text { for the country's } \\
\text { development, but } \\
\text { also symbolizes } \\
\text { Malaysia to become } \\
\text { a well-known } \\
\text { country among other } \\
\text { Muslim nation. }\end{array}$ \\
\hline
\end{tabular}


TABLE 1. Continue

\begin{tabular}{|c|c|c|c|c|c|}
\hline $\begin{array}{l}\text { Building } \\
\text { category }\end{array}$ & $\begin{array}{l}\text { Intention of portraying } \\
\text { political ideology by } \\
\text { building patron } \\
\text { (content) }\end{array}$ & $\begin{array}{l}\text { Influence of political } \\
\text { ideology on building } \\
\text { (expression) Form } \\
\text { (physical dimension) }\end{array}$ & $\begin{array}{l}\text { Architectural } \\
\text { characteristics }\end{array}$ & $\begin{array}{l}\text { Case study in } \\
\text { local scene }\end{array}$ & Findings \\
\hline $\begin{array}{l}\text { Commercial } \\
\text { building } \\
\text { (skyscraper) }\end{array}$ & $\begin{array}{l}\text { To assert identity in } \\
\text { the world by the KLCC } \\
\text { Holdings to showcase } \\
\text { Malaysia as wealthy } \\
\text { state in high-tech } \\
\text { industrialized } \\
\text { development by } \\
\text { - showing the country's } \\
\text { development is equal to } \\
\text { other developed nations } \\
\text { namely the West through } \\
\text { 'visible sign of progress' } \\
\text { 'be more noticeable and } \\
\text { to be more supreme.' }\end{array}$ & $\begin{array}{l}\text { d) Tall vertical scale } \\
\text { Scale draws attention to the } \\
\text { building's significance by } \\
\text { emphasizing its height, tall } \\
\text { vertical in height with } \\
\text { significant visibility as } \\
\text { landmark symbolize the } \\
\text { ruling body's economic } \\
\text { stature and country's status }\end{array}$ & $\begin{array}{l}\text { - Adopt modernistic } \\
\text { expressionism style approach } \\
\text { incorporates Islamic design } \\
\text { elements with modern } \\
\text { treatments } \\
\text { Designed to be structurally } \\
\text { resistant stands at } 451.9 \text { meter } \\
\text { - } 88 \text { storey tall. } \\
\text { Façade system of glass and } \\
\text { steel panels installed into } \\
\text { super high-strength reinforced } \\
\text { concrete designed to resemble } \\
\text { motifs found in Islamic art, a } \\
\text { reflection of Malaysia's } \\
\text { Muslim religion }\end{array}$ & $\begin{array}{l}\text { FIGURE 11. The Twin } \\
\text { Tower Petronas } \\
\text { (Ismail 2008) }\end{array}$ & $\begin{array}{l}\text { Architectural } \\
\text { attributes and } \\
\text { properties of the } \\
\text { Twin Tower } \\
\text { Petronas symbolizes } \\
\text { icon of modern } \\
\text { Malaysia. The } \\
\text { building was } \\
\text { architecturally } \\
\text { created as a symbol } \\
\text { of the evolution of } \\
\text { technology, } \\
\text { economic status } \\
\text { of the country } \\
\text { and Islamic tradition }\end{array}$ \\
\hline $\begin{array}{l}\text { Educational } \\
\text { institution } \\
\text { (University) }\end{array}$ & $\begin{array}{l}\text { To proclaim identity in } \\
\text { the global and local } \\
\text { scene as the reference } \\
\text { knowledge center for } \\
\text { Islamic Science by the } \\
\text { ruling Malaysian } \\
\text { government by } \\
\text { - erecting monumental } \\
\text { buildings with a } \\
\text { combination of modern } \\
\text { material technology } \\
\text { appearance with Islamic } \\
\text { architectural style } \\
\text { parallel to the } \\
\text { contemporary and } \\
\text { global audience's } \\
\text { preferences }\end{array}$ & $\begin{array}{l}\text { e) Distinct facade } \\
\text { A façade with a distinct } \\
\text { focal point ideally projects } \\
\text { a strong central focus, } \\
\text { enhancing the overall } \\
\text { perceptual stability. This } \\
\text { arrangement provides } \\
\text { symmetrical axis and order } \\
\text { while adding an element of } \\
\text { interest to the bland } \\
\text { monotonous façade when } \\
\text { differentiation exists in the } \\
\text { centre of the façade it } \\
\text { automatically attracts the } \\
\text { viewer's eye." This is } \\
\text { mostly seen in government } \\
\text { buildings. }\end{array}$ & $\begin{array}{l}\text { Building expresses a bland } \\
\text { concrete façade with colossal } \\
\text { columns stone veneers and } \\
\text { few decorative elements, } \\
\text { with long and wide glass } \\
\text { panels. } \\
\text { There is composition of } \\
\text { hierarchical order in its } \\
\text { arrangement at all levels. } \\
\text { The façade presents a distinct } \\
\text { focal point, which influences } \\
\text { the whole composition by the } \\
\text { large blue dome shaped } \\
\text { covering the roof top. } \\
\text { This central fulcrum, which } \\
\text { is presented by a protruding } \\
\text { dome on top of the roof, } \\
\text { breaks the horizontality of } \\
\text { the colossal columns. } \\
\text { The distinct centre not only } \\
\text { gives perceptual weight within } \\
\text { the overall composition but it } \\
\text { also indirectly heightens the } \\
\text { audience's emotion towards } \\
\text { vision and mission of the } \\
\text { university in parallel with the } \\
\text { ruling government interest and } \\
\text { political agenda. }\end{array}$ & $\begin{array}{l}\text { FIGURE 12. Universiti } \\
\text { Sains Islam Malaysia } \\
\text { (Ismail 2008) }\end{array}$ & $\begin{array}{l}\text { Architectural } \\
\text { attributes and } \\
\text { properties of } \\
\text { Universiti Sains } \\
\text { Islam Malaysia } \\
\text { (USIM) symbolizes } \\
\text { the icon of } \\
\text { Malaysian } 12^{\text {th }} \\
\text { university as center } \\
\text { that is based on } \\
\text { Islamic studies and } \\
\text { leads to new } \\
\text { knowledge in using } \\
\text { the latest } \\
\text { technologies. } \\
\text { The building was } \\
\text { architecturally } \\
\text { created to portray } \\
\text { the country's vision } \\
\text { to in produce } \\
\text { credible Islamic } \\
\text { leaders in } \\
\text { safeguarding the } \\
\text { full interests of the } \\
\text { nation and Muslims. } \\
\text { This is important to } \\
\text { make Malaysia as } \\
\text { major model of } \\
\text { Islamic countries in } \\
\text { the world and } \\
\text { becoming the center } \\
\text { of educational } \\
\text { excellence towards } \\
\text { the construction of } \\
\text { modern Islamic } \\
\text { civilization. }\end{array}$ \\
\hline
\end{tabular}

spaces for the convenience of the community as main user group since they are the ones who utilise public buildings at all times. This study also strove to give credence to the idea that one must be imbued with the proper knowledge of architectural history and politics in order to make a balanced judgment in formulating design theory for building a mosque. Although this paper presents how and why government leaders utilise architecture as a political tool in society, this paper does not posit architectural expression as a solution to be adopted by the government in order to overcome the social struggle which occurs in society including solving other cultural issues. An overview of the relationship between political ideology and architectural form presented in this paper is important as it focuses on architecture as a form of communication, and how the form characteristics symbolize political power from the introduction of new 
methodology from semiotics framework. This is important, as built form in the present context has also become part of the ruling authority's political agenda particularly in the newly independent countries.

\section{REFERENCES}

Aureli, P.V. 2008. The Project of Autonomy: Politics and Architecture Within and Against Capitalism. Volume 4. Princeton Architectural Press.

Barthes, R. 1967. Elements of Semiology. London: Jonathan Cape.

Barthes, R. 1988. The Semiotic Challenge. Oxford: Basil Blackwell.

Böhme, G. 2014. Urban atmospheres: Charting New Directions For Architecture and Urban Planning. Architectural Atmospheres. On the Experience and Politics of Architecture. Basel, Switzerland: Birkhäuser: 42-59.

Borch, C., Böhme, G., Eliasson, O. \& Pallasmaa, J., 2014. Architectural Atmospheres: On the Experience and Politics of Architecture. Walter de Gruyter.

Chandler, D. 2017. Semiotics: The Basics. Routledge.

Ching, F.D.K. 1996. Form Space and Order. USA: Van Nostrand Reinhold.

Coaldrake, W. 2002. Architecture and Authority in Japan. Routledge.

Dovey, K. 2014. Framing Places: Mediating Power in Built Form. Routledge.

Fiske, J. 1990. Introduction to Communication Studies. London: Routledge.

Gale, R. 2004. The multicultural city and the politics of religious architecture: urban planning, mosques and meaning-making in Birmingham, UK. Built Environment 30(1): 30-44.

Goodman, N. 1998. Reconceptions in Philosophy. Indianapolis: Hacket.

Gottdiener, M. 1995. Post Modern Semiotics: Material Culture and the Forms of Postmodern Life. U.K: Blackwell.

Gottdiener, M. 2003. Recapturing The Center: A Semiotic Analysis of Shopping Malls. In Designing Cities. Critical Readings in Urban Design. U.K: Blackwell Publishers.

Habraken, N.J. 2000. The Structure of the Ordinary: Form and Control in the Built Environment. MIT press.

Hawkes, T. 2003. Structuralism and Semiotics. London: Routledge.

Hirst, P. 2005. Space and Power: Politics, War and Architecture. Polity.

Holdcroft, D. 1991. Saussure: Signs, Systems and Arbitrariness. U.S.A: Cambridge University Press.

Hurwitz, W.L. 1993. Semiotics and Communication: Signs, Codes, Cultures. Hillsdale N.J: Laurence Erlbaum Associates.

Ismail, A.S. 2008. Discourse of Democratic Architecture in Malaysia: An Analysis of Putrajaya Government Building in Comparison to Parliament Building. Engaging Malaysia Modernity 50 Years and Beyond. UNIMAS.
Ismail, A.S. \& Rasdi, M.T.M. 2010. Mosque architecture and political agenda in twentieth-century Malaysia. The Journal of Architecture 15(2): 137-152.

Jones, B.D. 2001. Politics and the Architecture of Choice: Bounded Rationality and Governance. University of Chicago Press.

King, A. 2004. Spaces of Global Cultures: Architecture, Urbanism, Identity. London: Routledge.

Leeuwen, T. V. 2005. Introducing Social Semiotics. London: Routledge.

Leucking, S. 2002. Principles of Three Dimensional Design, Objects, Space and Meaning. New Jersey: Pearson Education.

MacGregor, R.N. 1985. The role of context, code, and caption in the analysis of creative behavior. Interchange 16(1): 85-93.

Nitzan-Shiftan, A. 2005. Capital city or spiritual center? The politics of architecture in Post-1967 Jerusalem. Cities 22(3): 229-240.

Peters, W. 2004. Apartheid politics and architecture in South Africa. Social Identities 10(4): 537-547.

Rapoport, A. 1988. Levels of meaning in the built environment. Cross-Cultural Perspectives in Nonverbal Communication, 317-336.

Rowland, I.D. \& Howe, T.N. eds. 2001. Vitruvius: Ten Books On Architecture. Cambridge University Press.

Saussure, F. de. 1966. Course in general linguistics. In collaboration with Albert Riedlinger, edited by Charler Bally and Albert Sechehaye. Wade Baskin New York: McGraw-Hill Book Company.

Smith, D. 2001. Architectural Context: A Peircean Frame, presentation to Institute for Studies in Pragmaticism. USA: Texas Technology University.

Sonne, W. 2004. Representing The State: Capital City Planning in the Early 20 $0^{\text {th }}$ Century. New York: Prestel.

Sudjic, D. 2005. The Edifice Complex. Allen Lane: Penguin Books Ltd.

Vale, J. L. 1992. Architecture, Power and National Identity. New Haven, London: Yale University Press.

Venturi, R. \& Brown, D.S. 2004. Architecture as Signs and Systems. Belknap Press.

Weber, R. 1995. On the Aesthetic of Architecture: A Psychological Approach to the Structure and Order of Perceived Architectural Space. UK: Avebury.

Whyte, W. 2006. How do buildings mean? Some issues of interpretation in the history of architecture. History and Theory 45(2): 153-177.

*Alice Sabrina Ismail, Erna Nuralia Zhaharin

Department of Architecture

Universiti Teknologi Malaysia

81310 UTM Skudai, Johor, Malaysia.

*Corresponding author, e-mail: b-alice@utm.my

Received date: $9^{\text {th }}$ September 2017

Accepted date: $20^{\text {th }}$ November 2017

In Press date: $15^{\text {th }}$ December 2017

Published date: $31^{\text {st }}$ December 2017 